\title{
Lessons in School Reform: Recent American Writings on Education
}

\author{
Mark Harrison
}

John Chubb \& Terry Moe, Politics, Markets and America's Schools, Brookings Institution, Washington, 1990.

Myron Lieberman, Public Education: An Autopsy, Harvard University Press, Cambridge, Mass., 1993.

Thomas Sowell, Inside American Education: The Decline, The Deception, The Dogmas, The Free Press, New York, 1993.

I n 1983 the US National Commission on Excellence in Education released $A$ Nation at Risk, an influential report that exemplified widespread dissatisfaction with American education. The report was highly critical of schools, alleging that academic standards were unacceptably low, especially in the more rigorous subjects such as maths and science. America's children were not learning basic skills.

Standardised test data provided hard evidence of the decline. American students lagged far behind those of most other advanced nations in maths and science proficiency. High-school graduates were sub-standard in literacy, writing proficiency and knowledge of history and literature. Scholastic Aptitude Test (SAT) scores had fallen throughout the 1970 s, reflecting a decrease in the academic achievement of America's most capable young people (especially in verbal skills) that was not due to changes in the number or the socioeconomic or racial mix of those taking the SAT (Murray \& Herrnstein, 1992).

$A$ Nation at Risk spurred a national crusade for educational reform. Over the last decade, States across America have implemented many changes, such as school-based management, public-school choice and teacher pay and certification changes. But discontent with American public education remains. Despite some

Mark Harrison is Lecturer in Economics in the Faculty of Economics and Commerce at the Australian National University. 
rises in the 1980s, the maths SAT declined in 1991 and the verbal SAT hit an alltime low.

Despite differences, the American and the Australasian educational systems face similar problems, such as social stresses, curriculum changes towards political and social 'relevance' and away from traditional academic skills, powerful teacher unions, and massive and growing educational bureaucracies. But although Australia has followed American educational trends, it has not evaluated their effects because the educational establishment opposes the collection of hard evidence on student performance. Yet there is much dissatisfaction with public education. Employers, retiring teachers and professors deplore declining academic standards. Parents are disturbed by the neglect of traditional social values and discipline. The proportion of students in private schools has increased to more than 25 per cent as parents vote with their feet. Australian politicians have also espoused reform, since it is generally agreed that a country's competitive advantage depends increasingly on the quality of its workforce. The demand for better-educated workers is likely to increase.

Three recent books on public education in America provide a detailed analysis of what is wrong with public education. They argue that the changes of the past decade have not and cannot work, and suggest the major changes needed for real education reform. The message for Australia is that much of the current tinkering with public education is futile. Worse, it may divert attention from the real problems of public education, and discredit educational reform.

\section{The Importance of Autonomy}

In Politics, Markets and America's Schools, John Chubb and Terry Moe argue that the fundamental problems with public education lie in the institutions of educational governance. Past attempts at reform have failed because they simply called for new policies to be administered by the existing institutions of governance, which have themselves been left untouched.

Chubb and Moe are at their best in showing why the political system, dominated as it is by special interests, is poor at running education, and why only decentralised markets will promote effective schools. Their argument is backed by comprehensive empirical analysis using the High School and Beyond data set, containing information on the achievement, attitudes, activities and family background of some 60,000 students in more than 1,000 private and public schools. The data base was augmented by the Administrator and Teacher Survey, which closely questioned more than 10,000 teachers, principals and other staff members, providing information about school organisation.

Chubb and Moe examine the factors that make an effective school, and focus on student academic achievement. This is not the only indicator of school performance, but it is an important one, and is one of the main goals of all schools. Their analysis is certainly vastly superior to the Australian practice of measuring inputs (such as expenditure, pupil-teacher ratios and year-12 retention rates) and making wild claims about the benefits of public education. 
The authors find that

High performance schools differ in goals, leadership, personnel and educational practices from low performance schools. Their goals are clearer and more academically ambitious, their principals are stronger educational leaders, their teachers are more professional and harmonious, their coursework is more academically rigorous and their classrooms are more orderly and less bureaucratic. (p.187)

These findings are mainstream. A good school needs to be able to establish an identity and impose it on its pupils.

Many factors affect academic performance, and it is vital that the complicated relationships and interactions between the variables are taken into account. The main problem is in distinguishing school effects from non-school effects. Chubb and Moe do their best to control statistically for these factors. They find that the major influences were (in order of importance) student ability, school organisation, family background and student peers. The key result is that effective school organisation promotes academic achievement. School resources were unrelated to student achievement when the other relevant factors were taken into account, thus confirming earlier studies (summarised in Hanushek, 1989). How we spend is much more important than how much we spend: 'the performance problems of public schools have little or nothing to do with inadequate funding' (p.194).

To understand why some schools are better organised than others, Chubb and Moe examined economic resources, student bodies, parental involvement, bureaucratic influence and school-board influence. Outside influence can affect curriculum, instructional methods used in classrooms, disciplinary policy, the allocation of school funds, and the hiring, dismissing and transferring of teachers. They found that 'Autonomy has the strongest influence on the overall quality of school organisation of any factor that we examined. Bureaucracy is unambiguously bad for school organisation' (p.183).

Effective schools are subject to much less external administrative control than are ineffective schools. On every issue, effective schools experience less influence from superintendents and central-office administrators. High levels of independence from external authority tend to be associated with high levels of organisational effectiveness. External control over personnel policies were the greatest burden to effective performance.

The importance of autonomy stems from the nature of education itself, which is based on personal relationships and interactions, on continual feedback, and on the knowledge, skills and experience of teachers. The most important requirement for effective education is good teaching. But good teaching involves many intangible qualities, such as enthusiasm and creativity, which are inherently difficult to measure. At the school level, everyone knows who the good and bad teachers are. But good teaching is impossible to monitor from outside the school. 
Autonomy enables a school to develop its own identity, and gives a principal the chance to build up a team of teachers and to provide incentives to improve actual performance. The present system, in contrast, deliberately undermines school autonomy. A centralised bureaucracy with little discretion at the lower levels cannot encourage good teaching. The central department recruits teachers and determines pay and conditions. Principals have little say over staff incentives. Promotion is based on measurable indicators, such as seniority and qualifications, which are unrelated to good teaching. Autonomous schools are better able than central administrators to recognise and meet the needs of parents and students, whereas a central bureaucracy is unlikely to promote consumer satisfaction or respond to diverse needs.

In drawing policy conclusions, Chubb and Moe first examine the educational reforms of the 1980s and why they failed. Traditional reforms, such as toughening the curriculum, more rigorous standards for teacher certification, external exams, stricter accountability, increased teacher pay, and centrally administered merit pay, may improve matters but may also make them worse. These reforms are never put to the market test and often involve more bureaucracy. Furthermore, the system is still subject to special-interest group pressures, which can limit the benefits of the changes. School based management invariably involves leaving the traditional institutions of school control intact. The schools remain subordinate to the education department, which is held accountable by the public for what happens in the schools. So when the schools make the inevitable mistakes, central office resumes control or implements a host of new rules and regulations: "parts of the old bureaucracy are jettisoned only to be replaced by new ones' (p.201).

In Australia, school-based management seldom involves autonomy in personnel matters, which is perhaps the most crucial for educational success. Indeed, the trend is towards centralisation of industrial regulation of teaching at the national level (Marginson, 1993: 25).

The few choice and voucher reforms that have been introduced in the US have been 'too limited in scope to achieve significant reform' (p.209), though they have had positive consequences for the participants. In particular, the schools remain subject to political control from above, choice has been limited to public schools, and the supply of schools controlled. The most promising exercise in public-sector choice occurred in East Harlem. Teachers could set up their own schools; the schools had substantial autonomy; and parents were free to choose among schools. The result was an innovative and diverse school system. Student achievement increased dramatically, despite the dismal socioeconomic environment. This experiment provides evidence that choice benefits the poor. Chubb and Moe emphasise the need to give parents the right to choose among autonomous schools, and to allow new schools to emerge in response to parent and student demand, leaving schools that fail to attract support to go out of business.

Yet Chubb and Moe's policy recommendations are weak. After establisining the need for fundamental reform of educational governance, they call for a new ype of public system with market incentives (see West, 1992, for a detailed criticism). 
They seem to believe that the public system must prevail because it is democratic. In contrast, Myron Lieberman conducts an 'autopsy' on public education.

\section{Escaping from Public Education}

A prolific author of insightful books on education, Lieberman claims that the rationale of public education is dead. Public education no longer effectively fosters basic skills, scientific and cultural literacy, civic virtues and desirable habits and attitudes towards society and its institutions. Public education is beyond reform because of the difficulties inherent in government operation of schools.

Whereas Chubb and Moe focus on academic achievement, Lieberman adopts a broader perspective, including analysis of equality of opportunity, information provision, racial conflict and costs, as well as outcomes. He draws on a wide range of data and illustrates his arguments with detailed examples. The problems inherent in government operation of schools include an absence of candour when reporting educational achievement. Massive deceptions in the US were not revealed by educators, test experts or education reporters. Lieberman carefully analyses why this breakdown in information provision is inevitable under a public system: available information is usually prepared by the producers of education and serves their interests and objectives.

But would grades and report cards be less informative under a market system? Schools (especially for-profit schools) would have an incentive to reveal poor performance by other schools and, as they are more likely to be held accountable for poor educational performance, to dampen unrealistic expectations. The argument that grade inflation would be worse under a private system is inconsistent with the other argument that private schools would push their failures into the public system. It is also contrary to much empirical evidence. Grade inflation is rife in the public system and poor grades are a major reason why students switch out the Catholic system in the US.

Lieberman carefully debunks many criticisms of a market system. For example, on the role of advertising, he writes

Advertising would be more influential in publicising the availability of schools than in retaining their pupils. Parents who have direct contact with schools are likely to rely on their experience, not on advertising when deciding whether to keep their child in a particular school. (p.111)

Education involves a long-term relationship between producer and consumer and a heavy emphasis on producer reputations. Lieberman is careful not to adopt a double standard. He compares the role of advertising in a market system to its role in politics.

After all, public education is dependent on the election of public officials supportive of it, and advertising is routinely used to elect such officials. Is 
advertising for candidates for public office more informative and more objective than advertising for commercial products or services? Any such claim would be difficult to sustain. (p.97)

The social pressures that Lieberman identifies as weakening public education are all in evidence in Australia. They include low birth rates, the aging of the population, the decline in children's social capital, feminism, heterogeneity, juvenile crime, international economic competition, income levels, and the resurgence of pro market ideologies. Lieberman shows how the government's provision role conflicts with its consumer protection role, and how the conflict is resolved in favour of producers. The dominance of producers is nicely illustrated with numerous examples. The per pupil expenses that are usually quoted grossly underestimate the true costs of public education and public-teacher compensation. As in Australia, the figures exclude government superannuation contributions to public-school teachers, teacher-education costs (borne largely by the taxpayer), the cost of remedial instruction in higher education and business, private funds raised by public schools, and direct federal government payments to parents and students. On the evidence, Catholic schools appear to perform better (or no worse) than public schools. Given their lower costs, Catholic schools must be more efficient. Nor is there any evidence that public schools produce more beneficial externalities than private schools. Lieberman concludes that a market system would enhance efficiency, reduce the costs of the management of conflict resulting from diversity, and improve equality of opportunity. He provides a clear analysis of why equality of opportunity is pushed by producer interests, and how the public system fails to achieve it and instead redistributes income towards the upper middle class.

As in Australia, educational research and development is publicly provided and funded. Little is spent on research and development of new technology, especially labour-saving technology (unusual in a labour-intensive industry), or on market research. Instead, funds go on policy research, which services producers. The output is used primarily by other researchers rather than by practitioners. Most research on educational policy is largely a waste of resources.

Most of the problems with public education flow from producer domination: 'the costs of producer control and of an industry geared to political action instead of better service as the way to enhance producer benefits' (p.273). Yet Lieberman deplores 'the uncritical support for voucher plans that include several anticompetitive provisions. Parents' choices as consumers are limited by restrictions on producers' (p.295). The Milwaukee voucher plan for choice within public schools prevented economies of scale, prohibited the establishment of new schools to serve voucher students (so restricting entrepreneurship and innovation), limited the expansion of participating schools and, since parents were debarred from topping up vouchers, prevented suppliers from adding many improvements no matter how much customers were willing to pay for them. 'The Milwaukee plan is likely to turn out poorly precisely because it is not a competitive market system of education' (p.13). 
Choice among public schools, and other plans that ignore the need for free entry of new schools (including for-profit schools) and exit of inefficient ones cannot be considered valid expleriments with a competitive market system of education. (For more elaborate analysis of this issue, see Lieberman, 1989.) A voucher plan that includes private schools will not automatically give the benefits of a competitive market. The set of associated regulations is crucial. How would we achieve 'fair competition' between private and public schools? What regulatory and financial burdens should be placed on private schools? Under the current system, parents who send their children to public schools receive much larger subsidies than those who use private schools, giving a huge financial advantage to the public system. But public schools are at a regulatory disadvantage: they must accept all applicants and are prohibited from teaching religion. Burdening private schools with the rules that apply to the public sector would in effect destroy their raison d'etre. What is the appropriate level of financial assistance to private schools? When does the public sector financial advantage offset the regulatory disadvantage? Under true competition, the rules are the same for all competitors. But in education, the rules help determine the outcome. Competition is seldom based on product improvement; the public sector does not react to declining market share as a private company would, but often imposes additional regulatory and financial burdens on private schools.

To summarise, there is no commonly agreed on criteria or principle that tells us when competition between public and private schools is fair. The sector that holds the advantage characterises the rules as fair. . Fairness is assessed in terms of the rules under which the competition takes place. (p.8)

Lieberman's analysis is confirmed by the Australian experience. Australia currently has a quasi-voucher arrangement under which the Commonwealth government provides per head funding to parents at private schools. Parents can top up the grant, but this reduces the Commonwealth funding, so implicitly taxing additional educational expenditure (Fane, 1984). Regulation is determined by a political process dominated by public-sector interests. The Commonwealth and State governments heavily regulate private schools and use their powers to protect existing schools from competition. Although the thriving private sector in Australia brings substantial benefits, no one could claim that Australia currently has a market system or that it has solved the problems of public schooling.

Lieberman also explains why vouchers have not been successful politically, and sets out an educational reform agenda to manage the transition to a market system. He does not predict the outcome. The best market structure can change with new technologies: for example, a market process may result in education becoming a cottage industry or a big business franchise operation. His reform agenda includes vouchers redeemable in profit or not-for-profit, public or private schools. $\mathrm{He}$ warns, 'Even desirable nonmarket reforms may not be achievable in the absence of 
a market system' (p.278), as they are unlikely to be implemented if they threaten teachers' positions. He suggests giving teachers financial incentives, such as generous retirement benefits, to support change.

\section{The Hidden Curriculum}

Thomas Sowell's Inside American Education is a pleasure to read, but the content is frightening. After establishing the decline in American academic performance, Sowell launches a savage attack on the many dogmas and hidden agenda of the education establishment. The book is a valuable guide to the reality behind the jargon and rhetoric of educationalists.

Sowell takes apart fashionable educational dogmas, such as that learning must be enjoyable to be effective or that raising students' self-esteem will result in their intellectual development. He strongly criticises psychotherapeutic education as confusing thinking with feeling, so that students do not know what thinking is. He assails the proponents of 'relevance', the 'belief that current emotional responses are a reliable guide to the future usefulness or meaningfulness of education' (p.90), and suggests that the experience of others may be a better guide. He rejects the idea of teaching the 'whole person' as too ambitious and impossible to do in anything but a superficial sense (especially when basic skills cannot be taught properly). He destroys the educational arguments that are made in favour of multiculturalism and criticises making adherence to the ideological tenets of multiculturalism a condition of employment for teachers as an attempt to impose a new orthodoxy.

Sowell details the anti-intellectual and manipulative nature of the new school curriculum and its role in undermining the parent-child relationship and shared values. At the school level, 'affective education' or 'attitude clarification' uses classroom brainwashing to reshape attitudes, and usually proceeds by questioning parental moral authority. As a result, programs are misleadingly labelled and their specifics concealed from parents. The public system is open to domination by outside interest groups determined to get their message into the classroom. These include including business interests: for example a manufacturer of birth-control products supplies thousands of so-called 'sex education' kits to high schools. The result is 'all sorts of non-educational activities pouring into schools, relieving many teachers of the drudgery of teaching, and substituting more "exciting" world-saving crusades in place of the development of academic skills' (p.94).

Sowell questions whether the social objectives of the new curricula are worthwhile, and whether they can be, and have been, achieved through education. He gives evidence that in practice educational trends have contributed to many adverse social changes, often the opposite to the promised effects. Above all, the new curricula detract from the academic objective of schooling. Social-propaganda courses use up classroom time and crowd out teaching of basic skills.

Sowell is equally scathing about the performance of the higher-education sector in the US. Although beyond the scope of this review, he outlines the disastrous consequences of falling admission standards, racial quotas and politically correct 
ideology, all of which are relevant in Australian higher education. The intellectual calibre of public school teachers and university education departments is low. (Similar criticisms have been made in Australia; see Moore, 1993.) Sowell concludes that compulsory education courses for teachers, which effectively debar the competent from teaching, is the biggest liability of the public school system. The second biggest is the tenure and seniority system, which ensures that "There is simply no institutional pay-off to being a good teacher' (p.290). Sowell would destroy the credentialling monopoly exercised by schools and academic departments of education, and would buy out existing interests, such as education professors, with retirement bonuses. In addition, he emphasises the need to test and measure education results, and to take the choice of test out of the hands of those who are being monitored. Lastly, Sowell recommends some form of parental choice.

\section{Conclusion}

The three authors agree that the well-known problems of education are inherent in a public and politicised education system. Australia's education system faces similar difficulties and is likewise dominated by producer interests. All agree that the most serious barrier to improved performance is not lack of resources; more detailed management of public schools in no way ensures better results; and school-based management and public-school choice are not enough. Any real improvement must be by way of a move to a market system of education, driven by parental choice and freedom of entry for suppliers of education, including for-profit schools. In addition, Lieberman and Sowell emphasise the vital need for other reforms, often ignored in Australia. Teacher credentialling must be deregulated; and students must be tested by independent assessment agencies. In short, the state of government schools is a product of the system under which they operate.

\section{References}

Fane, G. (1984), Education Policy in Australia, Economic Planning Advisory Council, Canberra (Discussion Paper 84/08).

Hanushek, E. (1989), 'The Impact of Differential Expendiures on School Performance', Educational Researcher 18: 45-51.

Lieberman, M. (1989), Privatization and Educational Choice, St. Martins Press, New York.

Marginson, S. (1993), Education and Public Policy in Australia , Cambridge University Press, Melbourne.

Moore, S. (1993), 'Literacy and Teacher Training', Education Monitor 4(3): 11-13.

Murray, C. \& R. Herrnstein (1992), 'What's really behind the SAT-score decline?', The Public Interest 106: 32-56. 
100 Mark Harrison

West, E. (1992), 'Autonomy in School Provision: Meanings and Implications. A Review Essay', Economics of Education Review 11(4): 417-25.

Comments from Leanne Holmes and David Hughes are gratefully acknowledged. 